\title{
Sheltering is not gathering: A study with groups of siblings in institutional sheltering
}

\author{
Lígia Negrão Costa Taborda \\ Universidade Federal do Pará. \\ Celina Maria Colino Magalhães \\ Universidade Federal do Pará.
}

\begin{abstract}
Objective: To describe and analyze the interactions between children and their siblings in an institutional shelter. Method: Descriptive research with convenience sample carried out with seven groups of two or three siblings who were at the institution. Focal-subject observation techniques were used with focus on the siblings, noting the frequency, peers, and types of interaction among the siblings and other children. Results: There was a higher average interaction among siblings when they shared the dormitory; when they were in separate ones the interaction was higher with other children. The most common interaction categories were similarity, cooperation, and sharing for the peers in the same bedroom. Conclusion: The sheltering of siblings must have as main principle the maintenance of social and family bonds by strengthening the possibilities of interaction among them and their affective relationships. The simple gathering of siblings alone is not enough to guarantee such fact.
\end{abstract}

Keywords: institutional sheltering, shelter, siblings, interactions.

\section{INTRODUCTION}

Institutional sheltering as subject has been the aim of several researches in the past decades debating about the institutions' characteristics [1, 2], the sheltered children's profile [3, 4], the perception of children about sheltering [5], the perception of educators and their care practice $[1,6,7]$, its implication to development $[3,4,8]$, interactions among sheltered children $[9,10$, $11]$, family reunification $[12,13,14]$, among many others, which highlights the relevance and pertinence of the theme nowadays.

Since the modifications made to the Child and Adolescent Statute in Brazil (Estatuto da Criança e do Adolescente - ECA) children and adolescent are seen as subjects of right, in development, inserted in a given context, who demonstrate potentialities for their whole physical, cognitive, affective, and social development, also the family is understood by the current Brazilian legislation as the vital structure and ideal place for the full development of individuals [15]. However, in some cases the family stops having the protective role for the child and adolescent, offering risks to their development, which leads to the sheltering situation [16].

In the attempt to consolidate the sheltering institutions as a protection environment for children complementary laws were created, such as Law No. 12.010 [17] which modifies previous schemes in order to guarantee the children's and adolescents' rights to family living by preserving the family bonds, giving more responsibility for the institutions to present proposals in the cases of family reunification, organizing their files with current information of the children and adolescents in the shelter, the revaluation of their situations through reports, definition of maximum period of sheltering, evaluation of the sheltering institutions, among other things. There is also the Law No. 13.509 [18] which modifies the ECA by setting new 
deadlines and procedures for the adoption process, in addition to establishing new possibilities for destitution of family power, affective sponsorship, and it also regulates voluntarily giving children and adolescents up for adoption.

The main aspects presented by Law No. 13.509 [18] are regarding the change in deadlines in all processes that deal with children and adolescent in sheltering situation, regulating the reduction of the institutionalization period from 2 years to 18 months, reevaluating each case every three months, prioritizing the process when the child or adolescents has chronic disease or certain health needs, in addition to groups of siblings, also fixating the deadline (120 days) for concluding the process of family power destitution. Therefore, the aforementioned law represents a step forward in the debate about family and adoption and the development of children and adolescents facing the process of institutionalization.

Bronfenbrenner [19] stated in his studies that institutions for children may serve as broad environment for the development of children and adolescents. This microsystem is marked by a large number of activities, functions, interactions, as well as a welcoming environment with the potential to develop reciprocal relationship, balancing power and affection. On the other hand, the same author emphasizes that, even though the institution is a context that enables development it does not provide an equivalent of family for children. Thus, the sheltering service must have a provisory character until the factors that led to the protective measure are ceased, should the child be sent back to the family living as early as possible.

The sheltered children go through ruptures from the environment they were inserted and from important people to them, thus, the contact with a reference figure is crucial to lessen the discomfort of entering the institution [5,20]. When traumatic events lead to ruptures or weakness of the parental bonds, the fraternal bond is extremely important because it supports what is left of the primary connection, structuring themselves as source of affective, emotional, and social stimulation [21]

Therefore, the children and adolescents from the same family must not be separated when sent to sheltering services, unless it is their will or wish, or if there is any clear risk of violence [22]. Nonetheless, different researches $[4,9,10]$, have shown separation of groups of siblings in sheltering institutions, violating the right to family and community living.

One of the factors that can enable development is the attachment behavior. The author considers that there are several attachment situations; regarding biological needs, as when they are hungry, sick, tired, or frightened. Other situations are when they don't feel safe for having a certain person on their side, or when they wish to maintain affective contact. In this sense, older sibling in exceptional conditions (as the sheltering situation) may take the role of subsidiary attachment for their younger siblings [23].

Several studies $[3,4,24]$ have shown there is large amount of siblings in the institution in comparison to the total of children, therefore the study of interaction among them is crucial to understand the family dynamics and the strategies used by them facing sheltering situation when there is rupture with the original family.

In addition to it, the institutional sheltering of siblings deserves special attention due to the fact that it is more difficult to return to original family or to be inserted in substitute family (extensive or adopting family) when compared to individual sheltering [8]. In that author's opinion, this situation is due to the permanence of the original family in vulnerability situation, with the consequent impossibility of its reunification, or the fact that many siblings are still 
legally attached to their original family, making it impossible for them to be placed in a foster family, or also the preference of the adopting family for taking one child at a time, which frequently leads to the permanence of siblings in institutional sheltering for periods longer than 18 months.

Most studies in the area have demonstrated the importance of this type of interaction for the child development $[5,25,26,27]$. Those interactions have their own characteristics, peculiar to each peer, which go through time, covering therefore relations that are different from those that take place between not kindred peers.

In a study performed in Spain about relationship of siblings in sheltering institutions, understand that it is expected that siblings sheltered together in an institution develop strong complicity, comprehension and protection feelings [28]. The authors also state that among groups of sheltered siblings there might be patterns of relationship where the older ones might have towards the younger ones the role of father/mother, which must be taken into consideration when a family decides to adopt siblings.

A study tried to identify the perspectives about the original family of six children in institutional sheltering in the metropolitan area of São Paulo. The research demonstrated that the children created alternative family dynamic, different form those considered standard, in which the sheltered siblings gain important roles. In this study the children seek on their older siblings the emotional bonds and safety they first stablished with the family, therefore the older sibling assumes the role of connecting element between the younger siblings and their imposed sheltering condition [5].

Almeida [9], on her turn, tried to understand the social network of sheltered children, seeking to understand, ]under the children's perspective, how siblings and other children would appear in the network. The author interviewed seven groups of siblings, 18 children in total, aging form six to ten years old, in three different sheltering institutions in Ribeirão Preto, São Paulo, aiming at identifying who the children would look for in certain situations related to the care and daily activities for protection, education, emotional support and affective relations, play, and leisure. The main results show that the children's social network is composed mainly by the people from the shelter and the family, the siblings were the most common family members mentioned, specially regarding the roles for protection, emotional support and affective relations, and play and leisure. Also, the older siblings and the ones sheltered at the same institution are the ones most mentioned by the children in the study.

A study performed in Portugal aimed at characterizing the amplitude, intensity, meaning, and roles performed by different elements in the personal social network of 30 children and youngsters in institutional sheltering, with ages ranging from 10 to 24 years, with siblings sheltered in the same institution (17) or in other ones (13). The results showed that with regards to emotional support friends is the most frequent group to receive this type of support (89.5\%), the predominant contact among the interviewed ones and their daily contact was in the group of friends, for it is with them that these children/youngsters have more direct contact [29]. However, siblings have an important role in the sheltering environment, as the presence of siblings in the institution provides natural and emotional support, and sense of stability and belonging, also it is a facilitator for the child to remain in the shelter and have a sense of family continuity.

By analyzing the studies on siblings interaction it is acknowledged that siblings are important source of support facing this situation of distance from the family living, the sibling is 
frequently the person who the child seeks in given situations, in other words, they are the reference figures the child has when in situations that deal with care, protection, emotional support, affective relationship, as well as playing and leisure. It is also called attention to the physical proximity among siblings as a predominant factor for the maintenance of the bond, for such proximity enables or favors sharing experiences and feelings during the sheltering period [30].

Accordingly, other studies have pointed at the difficulties in maintaining the sheltered siblings together $[3,9,10,11,31]$, due to the usual separation according to age and gender, impeding the maintenance or creation of bonds, as well as recuperating the right to live in family.

Due to all the issues and critics raised about the early and prolonged child institutionalization, and the amount of siblings under protective measure, the preoccupation regarding the quality of the interactions carried out in institutional environments has increased, calling for studies that investigate the content and quality of interactions among children that are in those institutions with their siblings, giving emphasis to their peers and the content of these interactions.

\section{METHOD}

Descriptive study, complying with the ethic principles of research with human beings, according to the Resolution 196/96 CNS/MS, approved by the Research Ethics Committee (REC) from the Tropical Medicine Center of the Federal University of Pará CEP-ICS/UFPA, protocol No. 039/2009.

\section{Participants}

The research was performed with 18 children in institutional sheltering in the State of Pará, comprising seven groups of sibling from a total of 60 children sheltered in the institution. 
Table 1

Characterization of children by groups of siblings, period and reason for sheltering.

\begin{tabular}{|c|c|c|c|c|c|c|}
\hline $\begin{array}{l}\text { Group } \\
\text { code }\end{array}$ & $\begin{array}{l}\text { Children } \\
\text { code }\end{array}$ & Gender & Age & $\begin{array}{c}\text { Sheltering } \\
\text { period } \\
\text { (months) }\end{array}$ & Dormitory & Sheltering reason \\
\hline \multirow[t]{2}{*}{ Group 1} & I1 & $M$ & 2 years & 17 & D3 & \multirow{2}{*}{$\begin{array}{l}\text { Neglect and } \\
\text { abandonment }\end{array}$} \\
\hline & $\mathrm{I} 2$ & M & 9 months & 9 & D2 & \\
\hline \multirow[t]{3}{*}{ Group 2} & I3 & $\mathrm{F}$ & 6 years & 4 & D7 & \multirow{3}{*}{$\begin{array}{c}\text { Neglect and chemical } \\
\text { dependency }\end{array}$} \\
\hline & $\mathrm{I} 4$ & M & 4 years s & 4 & D5 & \\
\hline & I5 & $\mathrm{F}$ & $\begin{array}{l}1 \text { year and } \\
3 \text { months }\end{array}$ & 4 & D3 & \\
\hline \multirow[t]{3}{*}{ Group 3} & I6 & M & 9 months & 4 & D2 & \multirow{3}{*}{ Neglect } \\
\hline & I7 & M & 6 years & 4 & D7 & \\
\hline & I8 & $\mathrm{F}$ & 7 years & 4 & D7 & \\
\hline \multirow[t]{2}{*}{ Group 4} & I9 & $\mathrm{F}$ & 5 years & 11 & D6 & \multirow{2}{*}{$\begin{array}{l}\text { Neglect and } \\
\text { vulnerability }\end{array}$} \\
\hline & I10 & $\mathrm{F}$ & 10 months & 11 & D2 & \\
\hline \multirow[t]{2}{*}{ Group 5} & $\mathrm{I} 11$ & $\mathrm{M}$ & 6 years & 3 & D7 & \multirow{2}{*}{$\begin{array}{c}\text { Negligência e } \\
\text { vulnerabilidade }\end{array}$} \\
\hline & $\mathrm{I} 12$ & M & 6 years & 3 & D7 & \\
\hline \multirow[t]{3}{*}{ Group 6} & $\mathrm{I} 13$ & $\mathrm{~F}$ & 6 years & 3 & D7 & \multirow{3}{*}{$\begin{array}{c}\text { Neglect and chemical } \\
\text { dependency }\end{array}$} \\
\hline & $\mathrm{I} 14$ & $\mathrm{~F}$ & 5 years & 3 & D6 & \\
\hline & $\mathrm{I} 15$ & M & 2 years & 3 & D3 & \\
\hline \multirow[t]{3}{*}{ Group 7} & I16 & $\mathrm{F}$ & 6 years & 6 & D7 & \multirow{3}{*}{$\begin{array}{c}\text { Neglect and chemical } \\
\text { dependency }\end{array}$} \\
\hline & $\mathrm{I} 17$ & M & 4 years & 6 & D5 & \\
\hline & $\mathrm{I} 18$ & M & 11 months & 6 & D2 & \\
\hline
\end{tabular}

\section{Environment}

The research was carried out in the largest public sheltering institution in the State of Pará, located in the suburbs of Belém - Brazil. This institution shelters temporarily children from 0 to 6 years old, of both genders, whose integrity was threatened or violated due to situations known as abandonment, violence, or neglect. The organization distributes the children by dormitories according to their age, thus grouped as it follows: Dormitory I - children from 0 to five months; Dormitory II - 6 to 11 months. In Dormitory III - 12 to 24 months. Dormitory IV - 3 years old. Dormitory V - four years old. Dormitory VI - five years old; and Dormitory VII - sixyear-old children. The care routine, educational activities, meals, hygiene and leisure were performed according to the dormitory. The clothes, shoes, and toys were collectively used.

\section{Instruments and materials}

1. Children Characterization Form. Elaborated by Cavalcante [3], based on Weber and Kassobudski (1996), the instrument approaches the psychosocial condition of children that live in sheltering institutions and the like. The form is composed of open-ended and closedended questions about the following matters: personal identification (10 items), Family structure (19 items), history of institutionalization (30 items), current socio-legal situation (19 items), and child's health (16 items). Those forms were filled based on materials and documents (reports, statements, certificate, social studies) which were made available by the institution and/or direct collection of information with the staff, offering data about each child in the research. 
2. Register sheet for observational data. Elaborated by the researchers the instrument was created to aid the transcription process of the observation sessions of focal subjects. The form is comprised of two parts, the first contains information about the child (focal subject), children from the dorm, date, time, place of observation, and situation in which interactive episodes took place; the second part has a two-column chart, the one on the right divided by 30 seconds, and the other lines were spaces to add notes of the transcriptions.

3. Audiovisual Materials. Video camera to record the interactions among siblings in the shelter.

\section{Procedure}

The research was carried out in five stages.

Stage 1 - Initial contact. After the approval of the ethics committee the research project was presented to the director of the institution and all the technical staff. In this stage it was requested the access to the files of the institution, and handed in the copy of the approved document by the REC and the investigation proposal.

Stage 2 - Habituation period. Systematic visits to the environment work performed with the objective to becoming familiar with the children and institutional routines, as well as knowing the cases through documents and dialogs with the technical staff. In this stage the children were selected to be part of the study, using as criteria the presence of siblings in the same institution.

Stage 3 - Data collection for the children's characterization. Through the consultation of documents (reports, statements, certificate, social studies) made available by the institution and the dialogs with the technical staff the children characterization form was completed.

Stage 4 - Data collection through observation. The data collection of interactions was performed through observational sessions, recorded, using the focal-subject technique, with the target on each child. Each section lasted seven minutes, total of three sessions per child in two different days and shifts.

Stage 5 - Dada analysis

Data analysis of the form- the information regarding the siblings was taken in order to complete each side of the chart: identification of the children and process of institutionalization, which were used to characterize the groups of siblings.

Observational data analysis - the transcription of the episodes was carried out after the episodes were recorded and ranked according to a modified version of Lopes (2007).

1- Conflict: in this category were included interactions with aggressive behaviors as: kicking, pushing or hitting someone, or dispute of people, places, or objects.

Example: at the dormitories hallway I8 (seven-year-old girl) pulls I7's hair (six-year-old sibling) who was walking among other children. I7 cries and goes away.

2- Sharing: in this category were included the interactions that express behaviors of sharing toys, food, school supplies and other objects.

Example: at the dormitory hallway I4 (four-year-old boy) kicks the ball to a far distance, fetches it and places it at I17's foot (four-year-old boy), who, on his turn, kicks the ball towards him. Both keep playing and taking turns to who kicks the ball. 
3 - Cooperation/affection: in this category were included interactions that express behaviors of help, including physical, emotional and cognitive support.

Example: at the cafeteria I8 (seven-year-old girl) stops her meal and goes towards another table where S3 (4-year-old girl) had fallen from the chair. I8 pulls up S3 and puts her by the table, helping her to eat.

4 - Competition: included in this category are the behaviors that express compassion, including: who has the better shoe, toy or outfit, who runs faster, and others.

Example: at the cafeteria I7 (six-year-old boy) bets S4 (six-year-old boy) who finishes lunch first.

5- Similarity of behavior: here were included the categories of interactions that express mimic behaviors of others in plays, talks, and postures.

Example: at the shed I5 (15-months girl) walking by herself looks at S5 (2-year-old boy) who runs into the fence, grabs it and starts jumping up and down. I5 runs to the fence and jumps with S5.

The data from the interaction contents were present through graphics and tables comparing the frequency of interaction contents between siblings and non-siblings, from the same dormitory (intra group) and different dormitories (extra groups).

\section{RESULTS AND DISCUSSION}

For the analysis of interactive peers it was identified the interaction frequency of children with their siblings, with coetaneous (same dormitory/intra group) and non-coetaneous (different dormitory/extra group). Figure 1 shows the average frequency of interactions. 


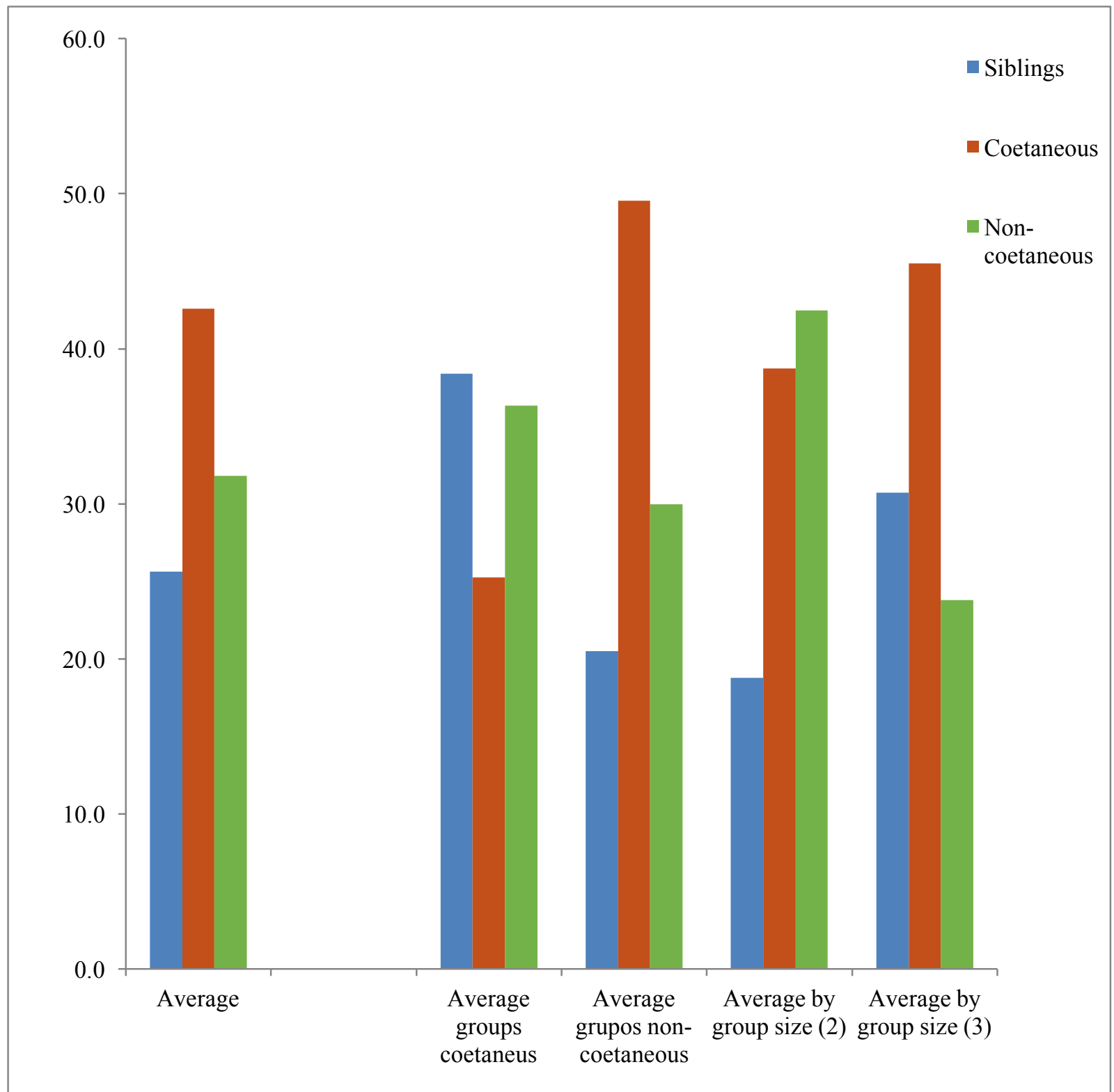

Figure 1. Average frequency of interaction among siblings, coetaneous and non-coetaneous.

A total of 501 interactions were registered, 27.7\% (139) of those were done only among siblings, 41.7\% (209) with siblings who shared the dormitory (coetaneous/intragroup), and $30.6 \%$ (153) of non-coetaneous siblings/extra group. When the analysis is done by groups it is noted a higher number of interactions of siblings who share the dormitory. When they are in different dormitories the children interact more frequently to coetaneous and non-coetaneous when compared to their siblings. It was also performed an analysis considering the size of the groups (two and three siblings), it was seen higher average frequency of interaction in the groups formed by three siblings, at least two at the same dormitory, in comparison to two siblings in separate dormitories.

The sociodemographic data of this study are similar to those found by Buiati et al. [24] that describes the process of institutional sheltering of biological siblings at the city of Uberada-MG, they investigated 40 groups of siblings sheltered in the year 2009, most of these groups were formed by two $(60 \%)$ or three $(25 \%)$ siblings. In most cases $(60 \%)$ they were sheltered at the same time. Nonetheless, the authors emphasize that these data do not reflect the total amount of siblings in those family units, for some of them are not sheltered. 
It is noteworthy mentioning that having siblings in the same institution does not guarantee the maintenance of family living and the maintenance of groups of siblings, for the environment conditions of the institutions may or may not favor the maintenance of such bonds as seen at the research [10]. In this last study done with four groups of siblings in Belém-PA, it was identified the frequency and content of interactions among siblings in the same institution. The results showed that the environmental factors of the institution, such as its large size, attending more than 50 children of a specific age range; with strict schedules and rules including the family visitation, the dormitory separation by age hence separating siblings, influenced the interactions among siblings leading to cases of complete lack of interaction among them. Similar fact was found in the present research, the data suggest that the environmental context of the institution favors few encounters of the siblings and do not guarantee effectively the strengthening and maintenance of the family bonds. However, low interactive frequency might be counterbalanced if there are interactions considered positive, in other words, interactions that strengthen the bonds.

Table 2

Frequency of categories of interaction among siblings, coetaneous and non-coetaneous

\begin{tabular}{|c|c|c|c|c|c|c|}
\hline & Group & $\begin{array}{l}\text { Cooperation/ } \\
\text { affection }\end{array}$ & Conflict & Sharing & Competition & $\begin{array}{c}\text { Similarity of } \\
\text { behavior }\end{array}$ \\
\hline & Siblings & 0 & 0 & 0 & 0 & 0 \\
\hline G1 & Coetaneous & 2 & 2 & 0 & 2 & 0 \\
\hline & Non-coetaneous & 1 & 2 & 5 & 1 & 7 \\
\hline & Siblings & 8 & 0 & 2 & 0 & 8 \\
\hline $\mathrm{G} 2$ & Coetaneous & 20 & 2 & 18 & 5 & 25 \\
\hline & Non-coetaneous & 6 & 4 & 5 & 1 & 12 \\
\hline & Siblings & 8 & 2 & 5 & 1 & 10 \\
\hline G3 & Coetaneous & 10 & 5 & 7 & 4 & 8 \\
\hline & Non-coetaneous & 9 & 5 & 6 & 4 & 9 \\
\hline & Siblings & 2 & 0 & 1 & 0 & 0 \\
\hline G4 & Coetaneous & 5 & 3 & 4 & 0 & 18 \\
\hline & Non-coetaneous & 1 & 2 & 0 & 0 & 4 \\
\hline & Siblings & 19 & 3 & 9 & 7 & 4 \\
\hline G5 & Coetaneous & 3 & 3 & 4 & 2 & 0 \\
\hline & Non-coetaneous & 5 & 4 & 7 & 10 & 6 \\
\hline & Siblings & 9 & 3 & 5 & 2 & 10 \\
\hline G6 & Coetaneous & 12 & 6 & 6 & 0 & 7 \\
\hline & Non-coetaneous & 5 & 3 & 1 & 2 & 6 \\
\hline & Siblings & 13 & 2 & 3 & 0 & 10 \\
\hline G7 & Coetaneous & 7 & 4 & 5 & 2 & 12 \\
\hline & Non-coetaneous & 1 & 2 & 2 & 0 & 4 \\
\hline TO' & & 146 & 57 & 95 & 43 & 160 \\
\hline
\end{tabular}

By analyzing the interaction categories of the sheltered siblings, the high ones with higher frequency were similarity, cooperation, and sharing. It is highlighted that these categories were prominent among peers of the same dormitory. These findings corroborate those found by Cavalcante [3] where the actions described as to provide help, cooperate, share, and comfort were ways the children helped, benefiting most commonly the peers in their immediate 
environment, usually children of the same dormitory. On the other hand, the least frequent behaviors in this research were conflict and competition.

The study done identified several cases in which the siblings were sheltered at the same institution but were then separated by program units in different places, situation that does not favor the necessary contact frequency among them [31]. The author also found situations similar to the ones in the present research regarding the distribution of children according to the age, forbidding siblings with different ages to stay at the same dormitory. Thus the institutional logic prevails over the children's affair.

With the intent to follow statutory principles the siblings were maintained in the same institution due to the same age range (zero to six years old), however, the institution's setting prevented them to establish family living and affective bonds. Therefore, it is questioned to what extent the right to family living and the maintenance of the groups of siblings is being respected because even though they were in the same institution the moments they had for this convivial were scarce.

The document Technical Orientations for the Sheltering Service for Children and Adolescent [22] focus on norms and guidelines for the sheltering of children and adolescents to be temporary, though remedial. To that matter it gives emphasis to preserving and strengthening family and commentary bonds. According to the document, these bonds are essential for providing conditions for a healthy development, favoring the identity formation and their construction as citizen and subject. In this sense, related children when sent to sheltering services cannot be separated, unless it is their desire and interest or if there is clear risk of violence.

The research results show that most siblings bonds are fragile due to the sheltering institution settings and their length of stay, for they spend more time on interaction with peers as opposed to their siblings.

For those children that are already apart from the family living it is specially critical to preserve and strengthen the fraternal and kindred bonds, which can contribute for their identity formation, preserving their life history and family references. For that matter, it is important the sheltering services to be organized in a way to provide care for groups of siblings or other kinship, either at different age range or gender.

In institutions for the care of children the daily living brings together children and adults, which clearly favors the expression of affection for the caretakers and the definition of preference to a certain peer, enabling to emerge relationships that value the intimate and affective contact between peers. In this study the most common interactions noted were among coetaneous [32].

The child after its second year of life tends to amplify its attachment behavior towards other people, usually those that replace the mother on its absence and provide the necessary care for their protection. In situations where there is the replacement of the person responsible for the child's routine care, as it happens in the institutional sheltering, it emerges the subsidiary figure of attachment, usually someone of its family living [26]. Therefore, the intimate and lasting convivial with a sibling who takes daily care of him/her might create favorable conditions for the definition of other attachment figures in the childhood. In group 7 probably the siblings performed the role of subsidiary attachment figures when faced with the 
sheltering situation, at the rate that on the other groups the coetaneous were the ones to have this role.

Several works $[3,9,10,26]$ demonstrate that the relationship between linked peers, as can be said about siblings, tend to be more intense and affective than those created with occasional peers. Older siblings in special occasions as sheltering may represent a subsidiary attachment figure for the younger ones. Nonetheless, it was also noted that in some cases the coetaneous, more frequently than the siblings have this role of subsidiary attachment figure [5].

The interaction among coetaneous peers makes possible a basis of equality and reciprocity and the children are exposed to differences between their point of view and of others, without having differences attributed to a higher position of knowledge of the peer, thus the children develop themselves in the sense that they can identify and confront distinct points of view, also such interactions create opportunities to develop the capacity of taking on different roles [33]. Therefore, those interactions are important throughout the children's development, however, interaction among siblings in sheltering situations must be encouraged because they already form a naturally linked peer and carry the history of their family and culture, which gives them identity.

The similarity of behaviors is present at the interactions among siblings and other children, coetaneous or not. Hinde [34] understands that the group has great influence on their way of thinking and behaving. Thus, the children tend to imitate the people they see as most similar to themselves, in other words, they mimic more the coetaneous than adults and non-coetaneous, or activities that they perceive as more similar to the ones they are performing [33] . For children in general, specially for those that live in institutions, their behaviors and attitudes are learned through imitation, common to the age researched, also by the physical proximity that facilitates the group cohesion, and by the individual's strategies of social adjustment [3].

Conflict was the second least frequent interaction (57 episodes) with fewer incidence among siblings in comparison to the other children, with the exceptions of group 5, in which it was more common among siblings, and 6 and 7 which had similar occurrence with children from different dormitories. Conflict is part of every relationship, though not always destructive [34]. Situational factors such as the search for privacy, autonomy, interdependence, and caring for their belongings, as well as the institution environment, its rules and norms, and the lack of individuality lead to conflicts among the children in institutional sheltering. The presence of this type of behavior depends on personal characteristics and nature of relationship [34]. Some situations in which children share their fears and anguishes, food and clothes, affection and protection in the institutional environment, in other words, collectively, they surpass the importance of the other forms of behavior and social interactions, hence the importance of acknowledging it for the preservation of their mental health, training of social skills and maturity of the human potential [3].

An adequate sheltering service must grant the children the maintenance of family bonds with their siblings, also grant the communication of children or adolescents with their family, have a physical structure similar to a house with few children, guarantee social and affective support system, with positive affective bonds in the institution environment, participation in the community and exchanges with the school [15], as well as offering the possibilities to express feelings, desires, anguishes, also respecting their individuality and singularity, with regards to clothes, toys, and objects [35]. Perhaps by following these guidelines the sheltering institution might be transformed into a better environment for child development. 
Although there were great changes in the country's legislation, first with ECA, then with the Law No. 12.010 [17] and with the technical orientations for the sheltering of children and adolescent, in practice, the changes happen slowly, and even though in some places the changes have already reached the shelters, the institution where this study took place still works as it did in the past, with characteristics of an orphanage. More than 20 years after implementing ECA few changes were seen on the structural organization of the institution. Even with orphanages becoming obsolete the culture of institutionalization and its vices may prevail, signaling the continuity of some old beliefs that support the work dynamic of such places [14].

That aspect was easily noted in the results of this research, once the contextual features of the institution such as the fact of being a large size institution attending more than 50 children at a certain age range, with well defined rules and schedules, including for the family visitation, segregation of children in dormitories by age, separating the siblings, all of them influence the siblings interactions.

The research results show an attempt of the siblings from groups 2 and 5 to have interaction among themselves, even though the institution wouldn't encourage their contact. It was also noted in this case differences in the interactions among siblings and with other children, demonstrating that the interactions among siblings are richer in cooperation when contrasted to those with occasional peers. $[3,10,26]$.

The results also suggest differences in the content of the interactions among siblings and children from the same dormitory, and those from different dormitories, as demonstrated by Hinde [36] who defends the idea that the content of the interactions depend on the nature of the relationship. These data point out to the importance of maintaining the family bonds, chiefly the fraternal ones, during the sheltering period. It is noteworthy bringing the attention to the reformulation of the institution so they have smaller size attending fewer children, have a residential character, or even restructure the service so it can provide the siblings with the possibility of growing up together and to support one another.

On that matter researchers affirm that the program of institutional sheltering must avoid specialization and selective attention to certain parts of the infantile-juvenile population by fixating limited age range, selecting them by disabilities, or HIV, or gender, to name some. In case there is the need to provide special attention to anyone, it must be done through the articulation with other public services or an adaptation of the institution and its environment [37].

It is yet understood that sheltering both genders and different age ranges in addition to contributing to respecting of the principal of non-separation of groups of siblings as envisioned by the statute, it also promotes the construction of the identity of children and adolescents for the daily contact with children of different age and gender favors the mutual stimulation and better performance at school activities, where the older ones stimulate the independence and development of younger children, as it happens in a family with children of different ages [37].

The right to the family and community living is held by the Brazilian Federal Constitution (1988) in article 277, emphasized by ECA [15] and prioritized at Law n.12.010 [17] and Law n.13.509 [18], and it is understood as the right to live among the family members under the protection of responsible parents, as well as taking part of the life in the community where the family lives. Regarding the group of siblings this right is also granted even for those sheltered 
in institutions, in the sense that having the appropriate conditions for creating or maintaining this bond is a way to respect this right.

Therefore it is considered that the organization of the institution's structure and routine based on the children age range barely favors the development or maintenance of affective bonds among groups of siblings. Therefore, for the reorganization to take place, in other words, for the environmental conditions to become favorable for the development, several changes would be necessary as: separation of the children into small sheltering units, with a residential character, few people, attending siblings at the same house granting their convivial; participation in community activities; personalized attention; housing children of different ages and genders, among other things.

In order to modify the reality found in the present study some urgent changes in the institution would be necessary regarding the reorganization, or in the short-term, restructuring the institution in a way to come closer to what is stated by ECA. The short term adaptations of the environment to attend the siblings demand involve: housing the groups of siblings in the same dormitory, allowing them to have meals, activities and plays together; the contact with the family including making the visitations easier, scheduling encounters with the parents and siblings; providing the opportunity to attend the same school; capacitating the educator to motivate the contact among siblings and recuperating their family history, among other possibilities.

In the medium-term it is expected that the policies regarding sheltering are implemented by governmental and non-governmental organizations, aiming at the reorganization of the service, in order for it to offer a family-like environment, with few children and adolescents, and enough caretakers who fit the profile and are technically adequate. Even though there are some of those actions already in practice, the current dynamics of sheltering institutions in general must be revaluated so it can be completely drawn apart from the precious model. The implementation of foster families represents a great improvement in that matter, even though this service is still scarce in the North of Brazil.

\section{FINAL CONSIDERATIONS}

This study aimed at investigating the interactions among siblings welcomed in sheltering institutions, considering the environmental factors of the institution and the influence it has on peers and the content of interactions. The results show that the routine in the institution for activities as to take a shower, sleep, eat, have access to areas as toy library and tv room are planned according to the dormitories, which impairs the interaction among siblings at different ages.

The data also showed that even when they were sheltered in different dormitories the siblings sought interactions with each other in some areas, even though the institution itself does not offer the best conditions for strengthening such bonds. Also, by analyzing groups of at least two siblings sheltered in the same dormitory it was noted a difference in frequency of interactions in comparison to the other groups of children. This fact unveil the importance of maintaining the bonds among siblings who are facing a change of scenery, being taken away from their families, also by the turnover of educators who work shifts or on daily schedules but are not there during the weekend. Thus, it is believed that these children undergo a different form of violence, besides that one that led them to the shelter, withdrawing them from their families, they also suffer with the lack of incentive to create bonds with a subsidiary attachment figure. 
A previous research done in this institution in 2010 also identified that the structure of the institution did not favor the maintenance of bonds among siblings, and emphasized the importance of such bonds to them, especially in a sheltering environment. The results of that research showed similar results, i.e. how the institution proceeded and its routine were not changed. In other words, the sheltering service is at the same time an environment where children are protected but also have their right to family and community living and permanence with their siblings even though they were at the same institution violated, for there were none or little incentives to their convivial.

It is believed that this study brings deliberations that can contribute for the reordering of the shelters in the region, assisting the construction of a politic-pedagogical project in the institution, considering the sheltering service as an environment for the development and protection of children. This research points out to the urgency to implement the legal provisions in the daily routine of the institution, making necessary the education of professionals who deal with the sheltered children, as well as reconsidering its structure, routine, and organization, in order to guarantee the integral development of children and adolescent and to grant their rights.

\section{References}

Corrêa, L. S. (2016). Serviços de acolhimento institucional de crianças e adolescentes na região metropolitana de Belém: Os ambientes, os acolhidos e os Educadores. (Tese de Doutorado). Programa de Pós-Graduação em Teoria e Pesquisa do Comportamento, Universidade Federal do Pará, Belém, PA, Brasil.

Souza, F. H. O. \& Brito, L. M. T. (2015). Acolhimento institucional de crianças e adolescentes em Aracaju. Psicologia Clínica, 27(1), 41-58.

Cavalcante, L.I. (2008). Ecologia do cuidado: interação entre a criança, o ambiente, os adultos e seus pares em instituições de abrigo (Tese de Doutorado), Universidade Federal do Pará, Belém, Pará, Brasil.

Serrano, S.A. (2008). 0 abrigamento de crianças de zero a seis anos de idade em Ribeirão Preto: caracterizando esse contexto (Tese de Doutorado), Universidade de São Paulo, Ribeirão Preto, SP, Brasil.

Müller, F. (2014). Perspectivas de crianças acolhidas institucionalmente sobre suas famílias de origem. Linhas Críticas, 20(41), 125-145

Corrêa, L.S. (2011). Concepções de desenvolvimento e práticas de cuidado à criança em ambiente de abrigo na perspectiva do nicho desenvolvimental (Dissertação de Mestrado), Programa de Pós-Graduação em Teoria e Pesquisa do Comportamento Universidade Federal do Pará, Belém, PA, Brasil.

Corrêa, L. S., Cavalcante, L.I.C., Silva, T.S.R. \& Dell'Aglio, D.D. (2011). Concepções sobre desenvolvimento e práticas de cuidado: educadores de abrigo em momentos de descanso e sono. In I. C. M. C. Magalhães, L.I.C. Cavalcante, F. A. R. Pontes, S. S. C. Silva \& L. S. Corrêa (Orgs.), Contextos ecológicos do desenvolvimento humano Belém: PakaTatu.

Silva E. R. A. $\mathrm{O}$ direito à convivência familiar e comunitária: os abrigos para crianças e adolescentes no Brasil. Brasília, DF: IPEA/CONANDA, 2004.

Almeida, I. G. (2009). Rede social e relacionamento entre irmãos: a perspectiva da criança em acolhimento institucional (Dissertação de Mestrado). Universidade de São Paulo, Ribeirão Preto, São Paulo, SP, Brasil.

Costa, L.N. (2011). Interações entre irmãos em acolhimento institucional: reflexões acerca das condições contextuais (Dissertação de Mestrado), Programa de Pós-Graduação em Teoria e Pesquisa do Comportamento, Universidade Federal do Pará, Belém, PA, Brasil.

Costa, L. N., Magalhães, C. M. C., \& Pedroso, J. S. (2014) Interactions between Siblings in Institutional Sheltering: A Case Study. Journal of Education and Human Development. 3(4), 155-166.

Brito, C. O. (2010). O Processo de Reinserção Familiar de Crianças e Adolescentes em Acolhimento Institucional (Dissertação de Mestrado), Programa de Pós-Graduação em Psicologia, Universidade Federal do Espírito Santo. Vitória, ES, Brasil.

Brito, C. O., Rosa, E. M., \& Trindade, Z. A. (2014). O Processo de Reinserção Familiar sob a Ótica das Equipes Técnicas das Instituições de Acolhimento. Temas em Psicologia, 22(2), 401-413. 
Silva, M. L. \& Arpini, D. M. (2013). 0 impacto da nova Lei Nacional de Adoção no acolhimento institucional: o ponto de vista de psicólogos e assistentes sociais que integram as equipes técnicas. Psicologia em Revista, 19(3), 422440 .

Lei n. 8.069, de 13 de julho de 1990 (1990). Dispõe sobre o Estatuto da Criança e do Adolescente e dá outras providências. Brasília, DF. Recuperado em 8 julho, 2017. http://www.planalto.gov.br/ccivil/LEIS/L8069.htm.

Conselho Nacional do Ministério Público (2013). Relatório da Infância e Juventude - Resolução nº 71/2011: Um olhar mais atento aos serviços de acolhimento de crianças e adolescentes no País. Brasília: Conselho Nacional do Ministério Público.

Lei n. 12.010, de 03 de agosto de 2009. (1990). Dispõe sobre adoção; altera as Leis n. 8.069, de 13 de julho de 1990 - Estatuto da Criança e do Adolescente, 8.560, de 29 de dezembro de 1992; revoga dispositivos da Lei no 10.406, de 10 de janeiro de 2002 - Código Civil, e da Consolidação das Leis do Trabalho - CLT, aprovada pelo Decreto-Lei no 5.452, de 1o de maio de 1943; e dá outras providências. Brasília, DF. Recuperado em 24 abril, 2018. http://www.planalto.gov.br/ccivil_03/_Ato2007-2010/2009/Lei/L12010.htm

Lei n. 13.509, de 22 de novembro de 2017. (2017). Dispõe sobre adoção e altera a Lei no 8.069, de 13 de julho de 1990 (Estatuto da Criança e do Adolescente), a Consolidação das Leis do Trabalho (CLT), aprovada pelo DecretoLei no 5.452, de 1o de maio de 1943, e a Lei no 10.406, de 10 de janeiro de 2002 (Código Civil). Brasília, DF. Recuperado em: 21 maio, 2018. http://www.planalto.gov.br/ ccivil_03/_ato2015-2018/2017/lei/L13509.htm

Bronfenbrenner, U. (1976/1996). A ecologia do desenvolvimento humano: Experiências naturais e planejadas (M. A. Verosese, trad.). Porto Alegre: Artes Médicas.

Bernal, E. M. B. (2004). Arquivos do abandono: Experiências de crianças e adolescentes internados em instituições do Serviço Social de Menores de São Paulo (1938 - 1960). São Paulo: Cortez.

Arnaud, M. (2003). Forme de résilience dans Le groupe fraternel. Le Divan familial, 1(10), 123-131.

Conselho Nacional dos Direitos da Criança e do Adolescente [CONANDA] \& Conselho Nacional de Assistência Social [CNAS] (orgs.). (2009). Orientações Técnicas: Serviços de Acolhimento para Crianças e Adolescentes. Brasília, DF.

Bowlby, J. (2002). Apego e perda: apego (A. Cabral, Trad.). São Paulo: Martins Fontes, 2002. (Original work published 1969).

Buiati, P. C., Ferreira, A. T. D., \& Gontijo, D. T. (2013) Caracterização dos processos de acolhimento institucional de grupos de irmãos. Revista de enfermagem e atenção à saúde; 2 (2), 69-83.

Brody, G. H., Stonerman, Z., \& Mackinnon, C. E. (1982). Role asymmetries in interaction among school-aged children, their young sibling e their friends. Child Development, 53(1), 1364-1370.

Carreño, C.M. \& Avilla, S.C. (2002). El vínculo de apego entre hermanos: un estúdio exploratório com niños colombianos de estrato bajo. Suma psicológica 9(1), 107-132.

Howe, N., \& Recchia, H (2006). Sibling relations and their impact on children's development. In Tremblay R. E., Barr R. G., \& Peters R. D. V. (eds.) Encyclopedia on Early Childhood Development [online]. Montreal, Quebec: Centre of Excellence for Early Childhood Development. Recuperado de http://www.childencyclopedia. com/ documents/Howe-RecchiaANGxp.pdf.

Palacios, J., Sánchez-Sandoval, Y., \& Léon, E. (2004). Adelante com la adopción. Junta de Andalucia, Consejería para la Igualdad y Bienestar Social, Universidad de Sevilla.

Teixeira, V. R. L. (2011). As Redes Sociais Pessoais de crianças e jovens em acolhimento residencial: 0 papel das fratrias (Dissertação de mestrado), Universidade do Minho, Portugal.

Almeida, I. G., Maehara, N. P., \& Rossetti-Ferreira, M. C. (2011). A perspectiva da criança em acolhimento institucional sobre sua rede social: a importância do relacionamento entre irmãos. In M. C. Rossetti-Ferreira, S. A. Serrano, \& I.G. Almeida (orgs.), 0 acolhimento institucional na perspectiva da criança. São Paulo: Hucitec.

Carreirão, U.L. (2005). Irmãos em abrigos: possibilidades e limites para o resgate do direito à convivência familiar e comunitária (Dissertação de Mestrado), Universidade Federal de Santa Catarina, Florianópolis, SC, Brasil.

Carvalho, A.M. (2000). Fatores contextuais na emergência do comportamento de cuidado entre crianças. Psicologia: Reflexão e Crítica, 13(1), 81-88.

Camaioni, L. (1980). L interazione tra bambini. Roma: Armando Armando.

Hinde, R. A. (1979). Towards understanding relationships, London: Academic Press. 
Abaid, J. L. W., Siqueira, A. C., \& Dell'Aglio, D. D. (2012). Implicações legais e desenvolvimentais no acolhimento institucional: possibilidades e desafios numa perspectiva psicológica. In D. M. Arpini \& A. C. Siqueira (Orgs.), Famílias e leis: Desafios à realidade brasileira. Santa Maria: Editora UFSM.

Hinde, R. A. (1976). Interactions, Relationships and Social Structure, Man 11(1):1 • March 1976.

Silva, E. R. A., \& Mello, S. G. (2004). Um retrato dos abrigos para crianças e adolescentes da Rede SAC: Características institucionais, forma de organização e serviços ofertados. In E. R. A. Silva (coord.) 0 direito à convivência familiar e comunitária: Os abrigos para crianças e adolescentes no Brasil. Brasília: IPEA/CONANDA. 